European

Thyroid Journal
Eur Thyroid J 2018;7:67-74

DOI: $10.1159 / 000485971$
Received: July 4, 2017

Accepted after revision: December 1, 2017

Published online: January 11, 2018

\title{
Thyroid Cancer Induction: Nitrates as Independent Risk Factors or Risk Modulators after Radiation Exposure, with a Focus on the Chernobyl Accident
}

\author{
Valentina M. Drozd ${ }^{a, b} \quad$ Igor Branovan ${ }^{b} \quad$ Nikolay Shiglik $^{b} \quad$ Johannes Biko $^{c}$ \\ Christoph Reiners ${ }^{a, c}$ \\ aThe International Fund "Help for patients with radiation-induced thyroid cancer 'Arnica'", Minsk, Belarus; ${ }^{\text {b Project }}$ \\ Chernobyl, Brooklyn, NY, USA; ${ }^{C}$ Clinic and Polyclinic of Nuclear Medicine, University of Würzburg, Würzburg, \\ Germany
}

\section{Keywords}

Thyroid cancer · Nitrate pollution · lonizing radiation · Chernobyl · Salivary glands · Risk stratification · Belarus

\begin{abstract}
In recent decades, differentiated thyroid cancer (DTC) incidence has been increasing worldwide. The important contributions to this phenomenon of "overdiagnosis" driven by wider use of improved ultrasound systems are amply documented, notwithstanding the "real" carcinogenic effects of ionizing radiation, e.g., from the Chernobyl accident or health care interventions. Less well understood is the role of nitrates - as environmental pollutants, in diet, and in medication - in thyroid carcinogenesis. Increasing exposure to nitrates is associated with rising incidence of esophageal, stomach, bladder, and colon cancers. Recent data suggest that in agricultural areas with higher mean nitrate levels in groundwater, DTC risk is also elevated. Our work in Belarus after Chernobyl has shown that children in districts with high nitrate concentrations in drinking water had significantly higher thyroid cancer incidence after irradiation than did their counterparts in areas with lower nitrate concentrations.
\end{abstract}

\begin{tabular}{ll}
\hline KARGER & ( 2018 The Author(s) \\
& Published by S. Karger AG, Basel Oparger \\
E-Mail karger@karger.com & This article is licensed under the Creative Commons Attribution- \\
www.karger.com/etj & $\begin{array}{l}\text { NonCommercial-NoDerivatives 4.0 International License (CC BY- } \\
\text { NC-ND) (http://www.karger.com/Services/OpenAccessLicense). } \\
\text { Usage and distribution for commercial purposes as well as any dis- } \\
\text { tribution of modified material requires written permission. }\end{array}$
\end{tabular}

Notwithstanding thyroid shielding, increasing use of computed tomography and dental X-rays heightens radiation exposure of the salivary glands in the general population, especially in children and adolescents. When nitrate intake is increased, salivary gland irradiation may potentially result in carcinogenic elevations in plasma nitric oxide concentrations. In conclusion, excess nitrate intake seems to be an independent risk factor for DTC. Additionally, we hypothesize from our data that high nitrate levels modulate the carcinogenic effect of radiation on the thyroid. Cohort studies, casecontrol studies, or both, are needed to quantify the effects of nitrates on DTC risk in the presence or absence of radiation exposure, e.g., that associated with diagnostic or therapeutic health care interventions.

(C) 2018 The Author(s)

Published by S. Karger AG, Basel

\section{Introduction}

During the last 30 years, the incidence of differentiated thyroid cancer (DTC) has steadily increased worldwide, most markedly in France, Italy, the Republic of Korea, Australia, and the USA [1-8]. In the USA, DTC incidence
Prof. Valentina M. Drozd, MD, PhD

The International Fund "Help for patients with radiation-induced thyroid cancer 'Arnica"” Zolotaya Gorka 11, 1, Minsk 220005 (Belarus)

E-Mail vm.drozd@gmail.com 
is rising more rapidly than that of any other malignancy except liver cancer [1], with the annual percent change (both genders) increasing from $2.4 \%$ in $1980-1997$ to $6.6 \%$ in 1997-2009 [2, 8]. In Europe, the increase in the last 2-3 decades has ranged from 5.3\% (Switzerland) to $155.6 \%$ (France).

In Belarus and Ukraine, DTC incidence has also substantially increased in the past 25 years; there is strong evidence that this increase was mainly due to radiation exposure of children and adolescents after the Chernobyl accident [9-11]. Nonetheless, an appreciable proportion of thyroid cancers diagnosed in young people in these countries may be related to screening or other confounders $[10,12]$.

The main factors contributing to the worldwide increase in the incidence of DTC continue to be debated. Today, it is generally accepted that the widespread use of ultrasound, introduced in the 1980s to diagnose structural thyroid diseases, has led to earlier, more frequent detection of this neoplasm. Better diagnostics were estimated to account for $60 \%$ or more of DTC diagnoses in 2003-2007 in women under the age of 80 years in France, Italy, the USA, Australia, and the Republic of Korea, and $30 \%$ or more in other very high-income countries [13]. Consistent with these estimates, small thyroid cancers that are best discovered using new technologies (ultrasound and fine-needle aspiration biopsy) have shown a sharply increased incidence [14]. However, improved medical surveillance and "overdiagnosis" do not completely explain the rise in rates of papillary thyroid carcinoma (PTC), since a significant increase also has been observed for larger tumors (>10 mm) [15-18].

\section{DTC and Radiation Exposure}

Also well accepted as an explanation for greater frequency of DTC diagnoses is radiation exposure. External radiotherapy in childhood for cancer, tinea capitis, or an enlarged thymus or tonsils has been long known to be associated with an elevated risk of DTC [19-21]. Additionally, DTC was the first solid tumor to be found in excess among atomic bomb survivors in Japan [22]. An updated pooled analysis of 12 studies [23] identified a consistent risk model across the full range of external radiation doses to the thyroid, with relative risk (RR) increasing approximately supralinearly through 2-4 Gy, and then leveling and declining above approximately $30 \mathrm{~Gy}$, although RRs remained elevated. Radiogenic effects occurred for both PTC and nonpapillary thyroid tumors. For doses
$>0.10 \mathrm{~Gy}$, RRs increased significantly with dose $(p<0.01)$, with no significant departure from linearity. The excess relative risk (ERR) estimate per Gy was significant within 10 years of radiation exposure at 2.76 (95\% CI: 0.94-4.98), and remained elevated 50 years and more after exposure [23].

In several other studies, dental radiography was associated with an increased risk of thyroid cancer [24, 25] and parotid gland tumors [26]. One case-control study [24] found a significant association between self-reported dental X-ray exposure, particularly multiple exposures, and DTC risk (odds ratio [OR]: 2.1, 95\% CI: 1.4-3.1, $p<$ $0.001)$ with a dose-response pattern $(p<0.0001$ for trend). American Dental Association recommendations stress the need to shield the thyroid during dental X-ray examination [27].

Pediatric DTC rates in Belarus began to increase as early as 4 years after the Chernobyl accident $[28,29]$. Ecological studies of DTC incidence in Belarus and Ukraine following Chernobyl estimated a linear ERR per Gy of 18.9 and excess absolute risk per Gy of 2.7 [9]. Cohort studies with measurement-based individual thyroid dose estimates reported ERRs per Gy of 5.3 and 2.2 for DTC in Ukraine and Belarus [11,30-35], respectively.

\section{Nitrates as Pollutants, in Diet, and in Medication}

Beyond diagnostic activity and radiation exposure, additional factors may contribute to increased DTC incidence, and require further investigation. In particular, nutritional exposure to chemical pollutants such as nitrates in drinking water, specifically during intrauterine life and early childhood, might affect thyroid cell propensity to mutagenesis. In general, there are five primary sources of exposure to nitrate and its metabolite nitrite: environmental/atmospheric exposure to nitric oxide (NO) and nitrogen, dietary exposure to nitrate and nitrite in food and in drinking water, and endogenous production of $\mathrm{NO}$ and swallowing of nitrate-rich saliva [36, 37].

The largest proportion of reactive nitrogen, i.e., NO, nitrogen dioxide, nitric acid, nitrous oxide, nitrite, nitrate, ammonia, nitrogen oxides, and organic compounds such as urea, amines, proteins, and nucleic acids, in the environment comes from agriculture in the form of fertilizers and animal waste $[38,39]$. The past 60 years have witnessed an exponential increase in the use of nitrogenrich manure and reactive nitrogen as fertilizers [40]. Although they boost agricultural productivity, nitrogen- 
rich fertilizers let nitrates seep through the soil into both groundwater and surface water. There, these substances can accumulate for years until the concentration is adverse to human health. Because of water pollution, high amounts of nitrate might be present in fruits and vegetables, specifically those grown in greenhouses. Additionally, high nitrate levels may be found in cured and processed meats due to the addition of these chemicals as preservatives or color enhancers. Medications, including antidiarrheals, diuretics, vasodilators, and the cytotoxic chemotherapy agent nitrosourea, also contribute to nitrate exposure in humans [39, 41].

In Belarus, between 1960 and 1990, mean use of nitrogen fertilizers increased more than 20-fold, from 4 to 92 $\mathrm{kg} /$ hectare, while the average nitrate concentration in groundwater rose almost 40 -fold, from 1.1 to $41.6 \mathrm{mg} / \mathrm{L}$ [42]. Groundwater from open wells is the main source of drinking water in rural Belarus. According to the Belarusian Ministry of Health, about $1 \%$ of pipeline water samples have nitrate concentration exceeding the World Health Organization (WHO)-recommended maximum contaminant level of $45 \mathrm{mg} / \mathrm{L}$ [43]. In contrast, about $40 \%$ of water samples from open wells exceed that maximum contaminant level. In Brest and Gomel Oblasts, the proportion of such samples reaches $40-60 \%$, while in Mogilev Oblast, it is about 20\% [43].

\section{Physiology and Pathophysiology of Nitrates}

In the past 30 years, the roles of $\mathrm{NO}$ in physiology and pathophysiology have been extensively studied. Nitrate is metabolized by the nitrate-nitrite-NO pathway. As a gas (in the pure state and under standard temperature and pressure conditions) with an unshared electron, NO participates in various biological processes. In the body, under normal oxygen pressure, $\mathrm{NO}$ is produced by $\mathrm{NO}$ synthetase from $\mathrm{L}$-arginine. In hypoxia, nitrite is reduced by a variety of reductases, including deoxyhemoglobin, to produce NO. Further reduction/oxidation of NO can lead to metabolite production (nitrogen dioxide, nitrate) [44].

Nitrate and NO are known to affect the iodine metabolism of the thyroid. Nitrate is a competitive inhibitor of the sodium-iodine symporter and prevents iodide uptake by the gland. Thyroid hormone synthesis is thereby compromised, leading to thyrotropin elevation. The resultant chronic thyroid stimulation can lead to proliferative changes, including hypertrophy and hyperplasia as well as neoplasia [45-47].

Nitrates and Thyroid Cancer Incidence
There are other mechanisms by which ingested nitrate may produce detrimental effects on health. One is through formation of methemoglobin, which inhibits the oxygencarrying capacity of blood; another is through endogenous formation of $\mathrm{N}$-nitroso compounds that may act as carcinogens $[41,46]$. Nitrosamine synthesis depends on temperature and $\mathrm{pH}$, and may be stimulated by low-level gamma radiation [48-50].

The salivary glands play a very important role in the metabolism of nitrate and the nitrate-nitrite-NO pathway $[36,37]$. Dietary nitrate is rapidly completely absorbed in the upper gastrointestinal tract. Sixty percent of ingested nitrate is excreted in the urine within $48 \mathrm{~h}[36,37]$. However, approximately $25 \%$ of circulating nitrate is taken up by the salivary glands and secreted into the mouth in saliva. Salivary nitrate concentrations are 10 - to 20 -fold above blood levels, and may reach several millimolars. Oral facultative anaerobic bacteria, residing mainly in the tongue's crypts, then reduce nitrate to nitrite and NO via nitrate-reducing enzymes. This relatively effective process results in nitrite levels that are 1,000-fold higher in saliva than in plasma.

\section{Nitrates and Radiotherapy}

Therapeutic irradiation increases $\mathrm{NO}$ levels in salivary gland tissue. NO produced in irradiated tissues mediates cellular regulation through posttranslational modification of a number of proteins [44]. Evidence exists for the role of $\mathrm{NO}$ as an intrinsic radiosensitizer [51]. On the other hand, administration of an NO synthesis inhibitor ameliorated the dysfunction of irradiated salivary glands, indicating that NO helps mediate the dry mouth symptoms occurring after irradiation [52].

Radiation-induced bystander effects may be modulated by NO [53-56]. NO synthase activation and NO overproduction after exposure to ionizing radiation not only affect bystander cells with activated NO synthase, but also can stimulate specific cell-signaling mechanisms. These $\mathrm{NO}$-dependent effects include the promotion of genomic instability and the accumulation of DNA reduplication errors in bystander cells, without the direct DNA damage seen in irradiated cells. Hydrophobic properties of NO, permitting the diffusion of the substance through the cytoplasm and plasma membranes, allow this signaling molecule to easily spread from irradiated cells to bystander cells without the involvement of gap-junctional intercellular communication [56]. 


\section{Nitrate Carcinogenicity: Relation to DTC}

The first report of negative health effects of nitrate, namely, methemoglobin formation, was in 1945, after observation of cyanosis in infants in Iowa, USA [57]. Longterm exposure to nitrate and nitrite has been evaluated in relation to multiple tumor types; positive associations were reported for cancers of the esophagus, stomach, bladder, and colon $[41,50]$.

$\mathrm{NO}$ as a carcinogen heavily depends on concentration in a nonlinear manner: the specific activity of this analyte at very low levels blocks tumor growth, while moderate concentrations promote tumor angiogenesis and cell survival via lymphocyte suppression [44]. High NO levels may induce chromosomal breaks directly, or indirectly by inhibiting DNA repair activities [58]. NO can cause irreversible injury to several fundamental cancer control genes. The substance plus superoxide rapidly react to form peroxynitrite, which can cause oxidative damage to DNA. NO can also block DNA synthesis through inhibition of ribonucleotide reductase, the rate-limiting enzyme in DNA production [58-60]. Additionally, NO can directly inhibit enzymes in the mitochondrial electron transport chain or act indirectly by interfering with DNA repair mechanisms, leaving the cell susceptible to other DNA-damaging agents [59]. NO has been shown to have a role in stimulating vascular endothelial growth factor-D (VEGF-D) expression in vitro [61]. The formation of the NO biomarker, nitrotyrosine, was also correlated with VEGF-D expression in human PTC. In that setting, NO may induce lymph node metastasis via VEGF-D stimulation. In vitro, NO has both genotoxic and metastasis-promoting properties. Increased NO generation in cancer cells may contribute to tumor hemangiogenesis or lymphangiogenesis by upregulating VEGF-D [61]. The effects of NO are mediated in part by its metabolites, such as peroxynitrite. Data suggest that NO stimulates CXC chemokine receptor 4 (CXCR4) expression in vitro [62]. Nitrotyrosine formation was also correlated with CXCR4 expression and lymph node metastasis in human PTC [62].

Regarding DTC, Ward et al. [63] found an increased risk of this neoplasm in agricultural areas with higher mean nitrate levels in public water supplies and with longer-term consumption of water with nitrate- $\mathrm{N}$ concentrations exceeding $5 \mathrm{mg} / \mathrm{L}$ (subjects with $\leq 5$ years' consumption at levels of $>5 \mathrm{mg} / \mathrm{L}$, RR: $2.6,95 \% \mathrm{CI}$ : 1.1-6.2). Increased dietary nitrate intake was associated with a heightened risk of DTC (RR: 2.9, 95\% CI: 1.0-8.1, $p=0.046)$ and with the prevalence of hypothyroidism
(OR: 1.2, 95\% CI: 1.1-1.4), but not hyperthyroidism [63].

With regard to thyroid radiation dose, de Vathaire et al. [64] investigated potential modifiers of the thyroid dose response to radiation therapy in survivors of pediatric solid tumors other than thyroid cancer. The risk of DTC as a second primary malignancy increased with a thyroid dose of up to $10 \mathrm{~Gy}$, then leveled off for higher doses. The excess RR per Gy of radiation to the thyroid was 4.7 (95\% CI: 1.7-22.6). Patients also receiving nitrosourea chemotherapy had a 6.6-fold (95\% CI: 2.5-15.7fold) higher risk than those who did not.

\section{Exposure to Nitrates and Radiation after Chernobyl}

Recently published data suggest a synergistic influence of nitrates in drinking water and the thyroid radiation dose on the incidence of childhood DTC in Belarus after the Chernobyl accident [12]. The highest mean thyroid dose (320 mGy) and the highest incidence of pediatric thyroid cancer in 1986-2005 (11 per 100,000 patientyears) was found in the most contaminated area, Gomel Oblast [12]. However, there was a notable exception to the general dose-incidence rate pattern, i.e., substantial difference in rates of pediatric thyroid cancer in Mogilev versus Brest Oblasts (1.50 vs. 5.51 per 100,000 patientyears). Whereas the estimated thyroid doses from iodine-131 were comparable in the two regions (65 vs. 51 $\mathrm{mGy}$ ), nitrate contamination of drinking water significantly differed (mean levels in open well water, 40 vs. 185 $\mathrm{mg} / \mathrm{L}$ ). Radiation dose was significantly associated with thyroid cancer incidence ( $p=0.029$ ), but the effect of radiation significantly varied according to the nitrate concentration in drinking water $(p=0.004)$. A plausible interpretation of these observations is that the radiation effect on thyroid cells might be modified by patients' ingestion of nitrate from drinking water [12]. Comparison of maps respectively showing levels of groundwater pollution by nitrates (Fig. 1a) and Chernobyl-related radiation doses (Fig. 1b) also suggests that both factors may influence DTC risk.

\section{Conclusions}

Based on our own experience and on published data, we hypothesize that thyroid cancer may be induced by coincidence of several conditions: (1) excessive nitrate uptake via drinking water increases nitrite production, 


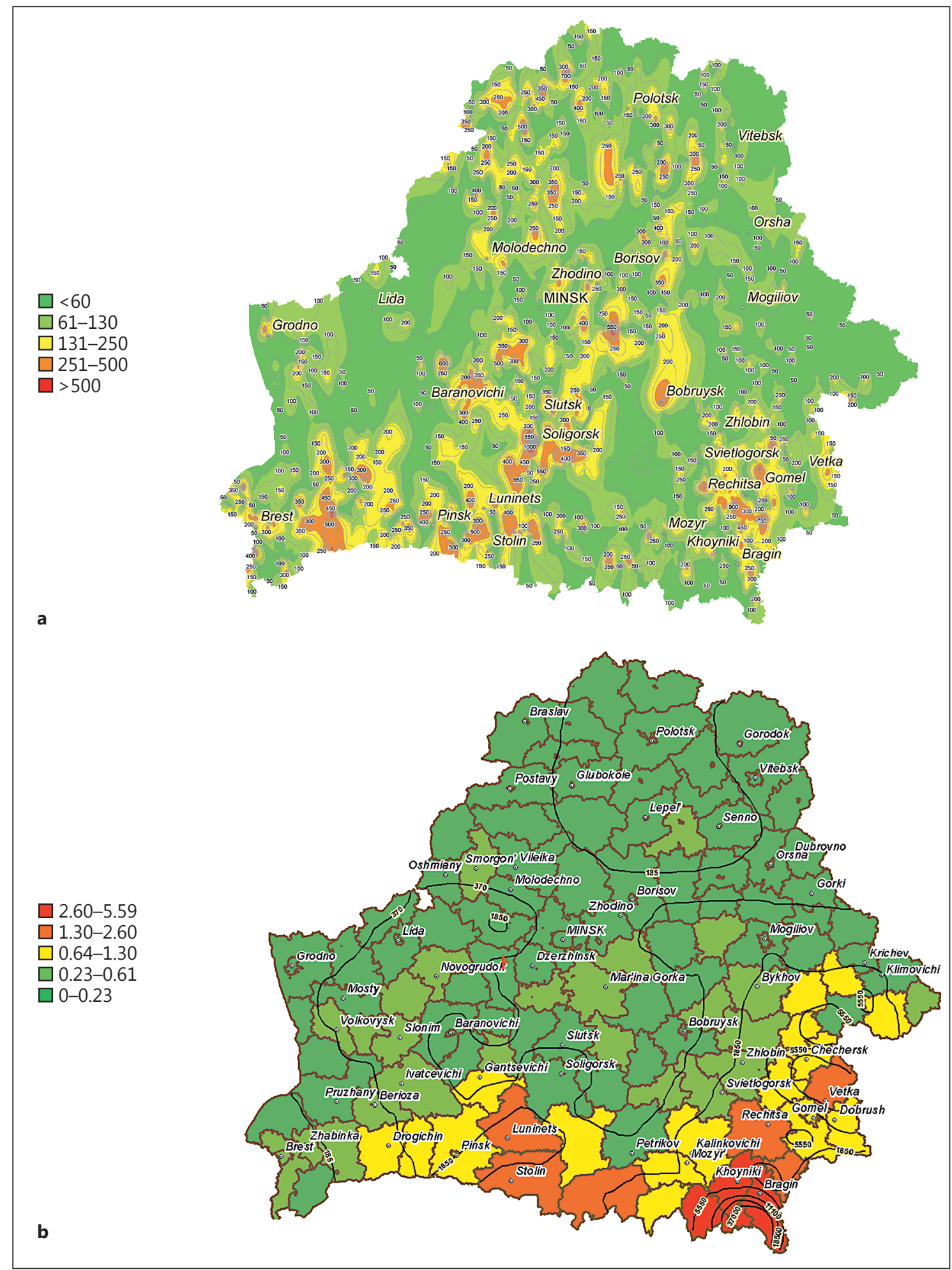

Fig. 1. Maps of Belarus depicting by district (oblast) the level of groundwater pollution with nitrate $(\mathrm{mg} / \mathrm{L})$ measured in open wells in 1988-1990 (a) and the prevalence (per 1,000) of pediatric thyroid cancer in 1986-2005 in the cohort ages 0-18 years at exposure to radioactive fallout from the Chernobyl accident (b). In $\mathbf{b}$, areas ex- posed to such fallout are bounded with black lines, and radioactive contamination due to radioiodine in 1986 (in $\mathrm{kBq} / \mathrm{m}^{2}$ ) is shown in small numerals. Notably, areas of greatest pediatric thyroid cancer prevalence tend to coincide with areas characterized by both a high radiation exposure and high nitrate pollution of groundwater. 
which leads to the development of hypoxia in the blood, especially in children, and to overproduction of $\mathrm{NO}$, which is carcinogenic per se; (2) radiation exposure of the salivary glands, e.g., by dental $\mathrm{X}$-ray examination, may also lead to increased plasma levels of NO; and (3) if one or both of these processes coincide with radiation exposure of the thyroid, the considerably increased NO concentrations in the body presumably enhance the carcinogenic effect of the radiation.

The role of radiation in thyroid carcinogenesis is well documented. The influence of other factors and confounders and their synergistic effects is less well understood. Studies of radiation-induced DTC in Belarus after the Chernobyl accident have shown that children living in areas with high nitrate concentration in drinking water have a significantly elevated thyroid cancer risk. A plausible interpretation is that the radiation effect might be modulated by ingested nitrates. Further cohort studies or case-control studies with individual exposure estimates are required to quantify the effect of nitrate on DTC risk in the context of growing use of medical radiation for diagnostic and therapeutic purposes. Such studies examining the increasing exposure to nitrates alone and in combination with ionizing radiation may provide a better understanding of the considerable increase in thyroid cancer incidence in many countries.

\section{Acknowledgments}

The authors are grateful for the important suggestions and contributions of Mary H. Ward, Senior Investigator, Occupational and Environmental Epidemiology Branch, Division of Cancer Epidemiology and Genetics, National Cancer Institute, Rockville, MD, USA. Robert J. Marlowe edited this paper.

\section{Disclosure Statement}

The authors have no conflicts of interest to disclose.

\section{References}

1 Merlo DF, Filiberti R, Kobernus M, Bartonova $A$, Gamulin M, Ferencic Z, Dusinska M, Fucic A: Cancer risk and the complexity of the interactions between environmental and host factors: HENVINET interactive diagrams as simple tools for exploring and understanding the scientific evidence. Environ Health 2012; 11(suppl 1):S9.

2 Pellegriti G, Frasca F, Regalbuto C, Squatrito $S$, Vigneri R: Worldwide increasing incidence of thyroid cancer: update on epidemiology and risk factors. J Cancer Epidemiol 2013; 2013:965212.

3 Nagataki S, Nystrom E: Epidemiology and primary prevention of thyroid cancer. Thyroid 2002;12:889-896.

4 World Health Organization: United Nations Environment Programme (WHOUNEP), State of the Science of Endocrine Disrupting Chemicals. 2012. http://www. who.int/ceh/publications/endocrine/en/index.html.

5 Wiltshire JJ, Drake TM, Uttley L, Balasubramanian SP: Systematic review of trends in the incidence rates of thyroid cancer. Thyroid 2016;26:1541-1552.

6 Cramer JD, Fu P, Harth KC, Margevicius S, Wilhelm SM: Analysis of the rising incidence of thyroid cancer using the Surveillance, Epidemiology and End Results National Cancer Data Registry. Surgery 2010;148:1147-1152; discussion 1152-1143.

7 Roche LM, Niu X, Pawlish KS, Henry KA: Thyroid cancer incidence in New Jersey: time trend, birth cohort and socioeconomic status analysis (1979-2006). JEnviron Public Health 2011;2011:850105

8 SEER: Cancer of the thyroid SEER Stat Fact Sheets. http://seer.cancer.gov/statfacts/html/ thyro.html (accessed February 14, 2017).

9 Jacob P, Bogdanova TI, Buglova E, Chepurniy M, Demidchik Y, Gavrilin Y, Kenigsberg J, Meckbach R, Schotola C, Shinkarev S, Tronko MD, Ulanovsky A, Vavilov S, Walsh L: Thyroid cancer risk in areas of Ukraine and Belarus affected by the Chernobyl accident. Radiat Res 2006;165:1-8.

10 Jacob P, Bogdanova TI, Buglova E, Chepurniy M, Demidchik Y, Gavrilin Y, Kenigsberg J, Kruk J, Schotola C, Shinkarev S, Tronko MD, Vavilov S: Thyroid cancer among Ukrainians and Belarusians who were children or adolescents at the time of the Chernobyl accident. J Radiol Protect 2006;26:51-67.

11 United Nations Scientific Committee on the Effects of Atomic Radiation: Sources and Effects of Ionizing Radiation, UNSCEAR 2008 Report to the General Assembly with Scientific Annexes. Annex D: Health effects due to radiation from the Chernobyl accident. New York, United Nations, 2008.

12 Drozd VM, Saenko VA, Brenner AV, Drozdovitch V, Pashkevich VI, Kudelsky AV, Demidchik YE, Branovan I, Shiglik N, Rogounovitch TI, Yamashita S, Biko J, Reiners C: Major factors affecting incidence of childhood thyroid cancer in Belarus after the Chernobyl accident: do nitrates in drinking water play a role? PLoS One 2015; 10: e0137226.

13 Vaccarella S, Dal Maso L, Laversanne M, Bray F, Plummer M, Franceschi S: The impact of diagnostic changes on the rise in thyroid cancer incidence: a population-based study in selected high-resource countries. Thyroid 2015; 25:1127-1136.

14 Ahn HS, Kim HJ, Welch HG: Korea's thyroidcancer "epidemic" - screening and overdiagnosis. N Engl J Med 2014;371:1765-1767.

15 Chen AY, Jemal A, Ward EM: Increasing incidence of differentiated thyroid cancer in the United States, 1988-2005. Cancer 2009;115: 3801-3807.

16 Enewold L, Zhu K, Ron E, Marrogi AJ, Stojadinovic A, Peoples GE, Devesa SS: Rising thyroid cancer incidence in the United States by demographic and tumor characteristics, 1980-2005. Cancer Epidemiol Biomarkers Prev 2009;18:784-791.

1717 Pathak KA, Leslie WD, Klonisch TC, Nason RW: The changing face of thyroid cancer in a population-based cohort. Cancer Med 2013;2:537-544.

18 Lim H, Devesa SS, Sosa JA, Check D, Kitahara CM: Trends in thyroid cancer incidence and mortality in the United States, 1974-2013. JAMA 2017;317:1338-1348.

19 Ron E, Lubin JH, Shore RE, Mabuchi K, Modan B, Pottern LM, Schneider AB, Tucker MA, Boice JD Jr: Thyroid cancer after exposure to external radiation: a pooled analysis of seven studies. Radiat Res 1995;141:259-277. 
20 Shore RE, Woodard E, Hildreth N, Dvoretsky P, Hempelmann L, Pasternack B: Thyroid tumors following thymus irradiation. J Natl Cancer Inst 1985;74:1177-1184.

21 Favus MJ, Schneider AB, Stachura ME, Arnold JE, Ryo UY, Pinsky SM, Colman M, Arnold MJ, Frohman LA: Thyroid cancer occurring as a late consequence of head-and-neck irradiation. Evaluation of 1,056 patients. N Engl J Med 1976;294:1019-1025.

22 Socolow EL, Hashizume A, Neriishi S, Niitani R: Thyroid carcinoma in man after exposure to ionizing radiation. A summary of the findings in Hiroshima and Nagasaki. N Engl J Med 1963;268:406-410.

23 Veiga LH, Holmberg E, Anderson H, Pottern L, Sadetzki S, Adams MJ, Sakata R, Schneider $A B$, Inskip P, Bhatti P, Johansson R, Neta G, Shore R, de Vathaire F, Damber L, Kleinerman R, Hawkins MM, Tucker M, Lundell M, Lubin JH: Thyroid cancer after childhood exposure to external radiation: an updated pooled analysis of 12 studies. Radiat Res 2016; 185:473-484.

24 Memon A, Godward S, Williams D, Siddique I, Al-Saleh K: Dental X-rays and the risk of thyroid cancer: a case-control study. Acta Oncol 2010;49:447-453.

25 Wingren G, Hallquist A, Hardell L: Diagnostic X-ray exposure and female papillary thyroid cancer: a pooled analysis of two Swedish studies. Eur J Cancer Prev 1997;6:550-556.

26 Preston-Martin S, Thomas DC, White SC, Cohen D: Prior exposure to medical and dental X-rays related to tumors of the parotid gland. J Natl Cancer Inst 1988;80:943-949.

27 American Dental Association Council on Scientific Advisory Affairs: The use of dental radiographs: update and recommendations. J Am Dent Assoc 2006;137:1304-1312.

28 Kazakov VS, Demidchik EP, Astakhova LN: Thyroid cancer after Chernobyl. Nature 1992; 359:21.

29 Cardis E, Kesminiene A, Ivanov V, Malakhova I, Shibata Y, Khrouch V, Drozdovitch V, Maceika E, Zvonova I, Vlassov O, Bouville A, Goulko G, Hoshi M, Abrosimov A, Anoshko J, Astakhova L, Chekin S, Demidchik E, Galanti R, Ito M, Korobova E, Lushnikov E, Maksioutov M, Masyakin V, Nerovnia A, Parshin V, Parshkov E, Piliptsevich N, Pinchera A, Polyakov S, Shabeka N, Suonio E, Tenet V, Tsyb A, Yamashita S, Williams D: Risk of thyroid cancer after exposure to ${ }^{131} \mathrm{I}$ in childhood. J Natl Cancer Inst 2005;97:724732.

30 Beal SH, Chen SL, Schneider PD, Martinez SR: An evaluation of lymph node yield and lymph node ratio in well-differentiated thyroid carcinoma. Am Surg 2010;76:28-32.

31 Astakhova LN, Anspaugh LR, Beebe GW, Bouville A, Drozdovitch VV, Garber V, Gavrilin YI, Khrouch VT, Kuvshinnikov AV, Kuzmenkov YN, Minenko VP, Moschik KV, Nalivko AS, Robbins J, Shemiakina EV, Shinkarev S, Tochitskaya SI, Waclawiw MA: Chernobyl-related thyroid cancer in children of Belarus: a case-control study. Radiat Res 1998;150:349-356.

32 Tronko MD, Howe GR, Bogdanova TI, Bouville $\mathrm{AC}$, Epstein OV, Brill AB, Likhtarev IA, Fink DJ, Markov VV, Greenebaum E, Olijnyk VA, Masnyk IJ, Shpak VM, McConnell RJ, Tereshchenko VP, Robbins J, Zvinchuk OV, Zablotska LB, Hatch M, Luckyanov NK, Ron E, Thomas TL, Voilleque PG, Beebe GW: A cohort study of thyroid cancer and other thyroid diseases after the Chernobyl accident: thyroid cancer in Ukraine detected during first screening. J Natl Cancer Inst 2006;98: 897-903.

33 Little MP, Kwon D, Zablotska LB, Brenner AV, Cahoon EK, Rozhko AV, Polyanskaya ON, Minenko VF, Golovanov I, Bouville A, Drozdovitch V: Impact of uncertainties in exposure assessment on thyroid cancer risk among persons in Belarus exposed as children or adolescents due to the Chernobyl accident. PLoS One 2015; 10:e0139826.

34 Zablotska LB, Ron E, Rozhko AV, Hatch M, Polyanskaya ON, Brenner AV, Lubin J, Romanov GN, McConnell RJ, O'Kane P, Evseenko VV, Drozdovitch VV, Luckyanov N, Minenko VF, Bouville A, Masyakin VB: Thyroid cancer risk in Belarus among children and adolescents exposed to radioiodine after the Chernobyl accident. Br J Cancer 2011;104: 181-187.

35 Zablotska LB, Nadyrov EA, Rozhko AV, Gong Z, Polyanskaya ON, McConnell RJ, O'Kane P, Brenner AV, Little MP, Ostroumova E, Bouville A, Drozdovitch V, Minenko V, Demidchik Y, Nerovnya A, Yauseyenka V, Savasteeva I, Nikonovich S, Mabuchi K, Hatch M: Analysis of thyroid malignant pathologic findings identified during 3 rounds of screening (1997-2008) of a cohort of children and adolescents from Belarus exposed to radioiodines after the Chernobyl accident. Cancer 2015;121:457-466.

36 Lundberg JO, Weitzberg E, Gladwin MT: The nitrate-nitrite-nitric oxide pathway in physiology and therapeutics. Nat Rev Drug Discov 2008;7:156-167.

37 Bryan NS, Loscalzo J (eds): Nitrite and Nitrate in Human Health and Disease. New York, Springer, 2011, p 306.

38 UNEP/WHRC: Reactive Nitrogen in the Environment: Too Much of a Good Thing? Paris/Falmouth, United Nations Environment Programme and the Woods Hole Research Center, 2007. http://www.unep.fr/scp/publications/details.asp?id=DTI/0904/PA (accessed April 12, 2012).

39 World Health Organization: Evaluation of certain food additives and contaminants. Forty-fourth report of the Joint FAO/WHO Expert Committee on Food Additives. WHO Technical Report Series 1995; No. 859. Geneva, WHO, 1995.

40 Townsend AR, Howarth RW: Fixing the global nitrogen problem. Sci Am 2010;302:64-71.

41 World Health Organization; International Agency for Research on Cancer: IARC Mono- graphs on the Evaluation of Carcinogenic Risks to Humans, 2010, V. 94: Ingested Nitrate and Nitrite, and Cyanobacterial Peptide Toxins. Lyon, IARC, 2010.

42 Kudelsky AV, Pashkevich VI, Kapora MS, VKavalenka MK: Quality of drinking groundwater of Belarus. Nat Res 2009;1:53-61.

43 Drozdova EV, Buraya VV, Rudik VA: Nitrate pollution of drinking water in Belarus: the analysis of the problem and arguments for further studies. Health Environ 2010;15:56-61.

4444 Scicinski J, Oronsky B, Ning S, Knox S, Peehl D, Kim MM, Langecker P, Fanger G: NO to cancer: The complex and multifaceted role of nitric oxide and the epigenetic nitric oxide donor, RRx-001. Redox Biol 2015;6:1-8.

45 Capen CC: Mechanistic data and risk assessment of selected toxic end points of the thyroid gland. Toxicol Pathol 1997;25:39-48.

46 Costamagna ME, Cabanillas AM, Coleoni AH, Pellizas CG, Masini-Repiso AM: Nitric oxide donors inhibit iodide transport and organification and induce morphological changes in cultured bovine thyroid cells. Thyroid 1998;8:1127-1135.

47 van Maanen JM, van Dijk A, Mulder K, de Baets MH, Menheere PC, van der Heide D, Mertens PL, Kleinjans JC: Consumption of drinking water with high nitrate levels causes hypertrophy of the thyroid. Toxicol Lett 1994; 72:365-374.

48 Ward MH: Too much of a good thing? Nitrate from nitrogen fertilizers and cancer. Rev Environ Health 2009;24:357-363.

49 Ohashi K, Tsutsumi M, Tsujiuchi T, Kobitsu K, Okajima E, Nakajima Y, Nakano H, Takahashi M, Mori Y, Konishi Y: Enhancement of $\mathrm{N}$-nitrosodiethylamine-initiated hepatocarcinogenesis caused by a colchicine-induced cell cycle disturbance in partially hepatectomized rats. Canc Res 1996;56:3474-3479.

50 Agency for Toxic Substances and Disease Registry (ATSDR): Toxicological Profile for N-Nitrosodimethylamine (Final Report). Atlanta, ATSDR, 1989.

51 Jordan BF, Sonveaux P, Feron O, Gregoire V, Beghein N, Dessy C, Gallez B: Nitric oxide as a radiosensitizer: evidence for an intrinsic role in addition to its effect on oxygen delivery and consumption. Intl J Cancer 2004;109:768773.

52 Takeda I, Kizu Y, Yoshitaka O, Saito I, Yamane GY: Possible role of nitric oxide in radiation-induced salivary gland dysfunction. Radiat Res 2003;159:465-470.

53 Nagasawa H, Little JB: Induction of sister chromatid exchanges by extremely low doses of alpha-particles. Cancer Res 1992;52:63946396.

54 Nagasawa H, Little JB: Unexpected sensitivity to the induction of mutations by very low doses of alpha-particle radiation: evidence for a bystander effect. Radiat Res 1999;152:552557.

55 Azzam EI, Little JB: The radiation-induced bystander effect: evidence and significance. Hum Exp Toxicol 2004;23:61-65. 
56 Yakovlev VA, Mikkelsen RB: Reactive nitrogen posttranslational modifications of proteins in carcinogenesis; in Laher I (ed): Systems Biology Free Radicals and Antioxidants. Springer, 2014, pp 2873-2891.

57 Comly HH: Landmark article Sept 8, 1945 Cyanosis in infants caused by nitrates in wellwater. By Hunter H. Comly. JAMA 1987;257: 2788-2792.

58 Roy B, Guittet O, Beuneu C, Lemaire G, Lepoivre M: Depletion of deoxyribonucleoside triphosphate pools in tumor cells by nitric oxide. Free Radic Biol Med 2004;36: 507-516.
59 Ghafourifar P, Colton CA: Compartmentalized nitrosation and nitration in mitochondria. Antioxid Redox Signal 2003;5:349-354.

60 Xu W, Liu LZ, Loizidou M, Ahmed M, Charles IG: The role of nitric oxide in cancer. Cell Res 2002; 12:311-320

61 Nakamura Y, Yasuoka H, Zuo H, Takamura Y, Miyauchi A, Nakamura M, Kakudo K: Nitric oxide in papillary thyroid carcinoma: Induction of vascular endothelial growth factor $\mathrm{D}$ and correlation with lymph node metastasis. J Clin Endocrinol Metab 2006;91:15821585 .

62 Yasuoka H, Kodama R, Hirokawa M, Takamura Y, Miyauchi A, Sanke T, Nakamura Y: CXCR4 expression in papillary thyroid carcinoma: Induction by nitric oxide and correlation with lymph node metastasis. BMC Cancer $2008 ; 8: 274$
63 Ward MH, Kilfoy BA, Weyer PJ, Anderson KE, Folsom AR, Cerhan JR: Nitrate intake and the risk of thyroid cancer and thyroid disease. Epidemiology 2010;21:389-395.

64 de Vathaire F, Haddy N, Allodji RS, Hawkins M, Guibout C, El-Fayech C, Teinturier C, Oberlin O, Pacquement H, Diop F, Kalhouche A, Benadjaoud M, Winter D, Jackson A, Bezin Mai-Quynh G, Benabdennebi A, Llanas D, Veres C, Munzer M, Nguyen TD, Bondiau PY, Berchery D, Laprie A, Deutsch E, Lefkopoulos D, Schlumberger M, Diallo I, Rubino C: Thyroid radiation dose and other risk factors of thyroid carcinoma following childhood cancer. J Clin Endocrinol Metab 2015;100:4282-4290. 